\title{
Dampak Pelaksanaan Program Nasional Pemberdayaan Masyarakat (PNPM) Mandiri Terhadap Peningkatan Pendapatan Masyarakat Miskin Desa Tompo Bulu Kecamatan Rumbia Kabupaten Jeneponto
}

\author{
Juhasdi Susono \\ Universitas Negeri Makassar \\ Juhasdimm@gmail.com
}

\begin{abstract}
The problem of this research is how the effect of revolving fund loans by the Mandiri National Community Empowerment Program (PNPM) on the income of the poor in Tompobulu Village, Rumbia Subdistrict, Jeneponto District. Rumbia District, Jeneponto Regency. This research is descriptive quantitative research with a sample design of this study amounting to 30 poor households. The research method used is simple regression analysis. The results obtained are revolving fund loans that have a positive and significant effect on increasing the incomes of the poor in Tompobulu Village, Rumbia District, Jeneponto Regency. It means that loans and loans given to the poor can increase the income of the poor in Tompobulu Village, Rumbia District, Jeneponto Regency.
\end{abstract}

Keywords: Mandiri PNPM, revolving fund loans, the poor and income

\begin{abstract}
Abstrak
Masalah penelitian ini adalah Bagaimana pengaruh pinjaman dana bergulir oleh Program Nasional Pemberdayaan Masyarakat (PNPM) Mandiri terhadap pendapatan Masyarakat Miskin di Desa Tompobulu Kecamatan Rumbia Kabupaten Jeneponto.Tujuan penelitan ini adalah untuk mengetahui Pengaruh program pinjaman dana bergulir oleh PNPM Mandiri terhadap pendapatan Masyarakat di Desa Tompobulu Kecamatan Rumbia Kabupaten Jeneponto. Penelitian ini merupakan penelitian Deskriptifkuantitatif dengan desain sampel penelitian ini berjumlah 30 orang Rumah tangga miskin. Metode penelitian yang digunakan adalah analisis regresi sederhana. Hasil yang diperoleh yaitu pinjaman dana bergulir berpengaruh positif dan signifikan terhadap peningkatan pendapatan masyarakat miskin di Desa Tompobulu Kecamatan Rumbia Kabupaten Jeneponto. Maksudnya pinjaman dan abergulir yang diberikan kepada masyarakat miskin dapat meningkatkan pendapatan masyarakat miskin di Desa Tompobulu Kecamatan Rumbia Kabupaten Jeneponto.
\end{abstract}

Kata kunci : PNPM Mandiri, Pinjaman dana bergulir,masyarakat miskin dan pendapatan

Jurnal Ilmiah Al Tsarwah

Program Magister Program Studi Ekonomi Syariah

Institut Agama Islam Negeri (IAIN) Bone 


\section{PENDAHULUAN}

Pembangunan ekonomi daerah merupakan proses dimana pemerintah daerah dan kelompok-kelompok masyarakat yang mengelola sumber daya yang ada serta membentuk pola kemitraan antara pemerintah daerah dengan sektor swasta untuk menciptakan suatu lapangan kerja baru dan merangsang kegiatan ekonomi nasional. Dunia usaha nasional mencakup dunia swasta (usaha kecil, menengah dan besar), BUMN dan koperasi.Ketiga dunia usaha ini harus melakukan sinergi diantara elemen yang ada, dan bukan berjalan sediri-sendiri sehingga dapat memperkuat struktur perekonomian nasional.

Pada dasamya pembangunan adalah proses perubahan yang terus menerus menuju kemajuan (progress) yang lebih baik. Pembangunan tanpa mengikutsertakan faktor sosial kemasyarakatan akan menjadi faktor penarik (pull) dan pendorong (push). Kedua faktor tersebut akan menghambat perkembangan keberlanjutan (continuity) dan keberlangsungan (sustainability) pembangunan akan terganggu akibat faktor kemasyarakatan yang kurang serius mendapatkan perhatian.

Kecamatan Rumbia merupakan salah satu wilayah kabupaten Jeneponto Propinsi Sulawesi Selatan,Jika dilihat dari keadaan penduduk miskin di Kecamatan Rumbiasampai tahun 2012 penduduk miskin di kecamatan Rumbia masih tergolong tinggi yaitu sebanyak 4.381 rumah tangga atau sebesar $55.68 \%$ dari total rumah tangga, sedangkan menurut desa rumah tangga miskin terbanyak adalah Desa Tompobulu yaitu sebesar 522 rumah tangga, menyusul desa Kassi yaitu sebesar 477 rumah tangga miskin.

Mulai tahun 2007 Pemerintah Indonesia merancang Program Nasional Pemberdayaan Masyarakat Mandiri (PNPM) yang terdiri dari PNPM Mandiri Perdesaan, PNPM Mandiri Peikotaan, serta PNPM Mandiri Wilayah Khusus dan Tertinggal. PNPM Mandiri Perdesaan adalah program yang mempercepat penanggulangan kemiskinan secara terpadu dan berkelanjutan.PNPM Mandiri Perdesaan merupakan kerangka yang

Jurnal Ilmiah Al Tsarwah

Program Magister Program Studi Ekonomi Syariah

Institut Agama Islam Negeri (IAIN) Bone 
berisi pedoman pedoman yang dipatuhi oleh program-program yang tergabung di dalamnya.Program-program yang termasuk dalam PNPM Mandiri Perdesaan ini mengikuti kerangka dan pedoman yang ditetapkan oleh Tim Pengendali PNPM Mandiri Perdesaan, termasuk didalamnya mengenai penentuan dan pembagian wilayah tempat program-program tersebut dilaksanakan.

Pedoman mengenai pelaksanaan program-program penanggulangan kemiskinan tersebut tertuang dalam keputusan Menteri Koordinator Bidang Kesejahteraan Rakyat Selaku Ketua Tim Koordinasi Penanggulangan Kemiskinan No.25/KEP/MENKO/KESRAmi/2007 Tentang Pedoman Umum Program Nasional Pemberdayaan Masyarakat Mandiri.Masyarakat yang dijadikan tujuan sasaran dari PNPM mandiri Perdesaan adalah rumah tangga miskin.PNPM Mandiri ini sekaligus merupakan pelaku utama dari setiap tahapan pelaksanaan PNPM Mandiri Perdesaan, mulai dari tahapan perencanaan sampai kepada pelaksanaan.

Salah satu program PNPM Mandiri untuk mengurangi kemiskinan adalah Program dana bergulir. Program dana bergulir pada PNPM pada hakekatnya melibatkan 3 (tiga) unsur dalam hal ini yaitu : (1) Unit Pengelola Kegiatan (UPK) sebagai pengelola dan penyalur seluruh dana bergulir di tingkat kecamatan. (2) Kelompok peminjam sebagai pengelola dan sekaligus penyalur dana bergulir kepada anggotanya pada tingkat desa. (3) Tim pengelola kegiatan di desa sebagai fasilisator antara kelompok peminjam dan UPK di tingkat kecamatan. Satu kelompok minimal terdiri dari 4 orang dan maksimal 10 orang.

Adapun mekanisme pelaksanaan dana bergulir diawali oleh kelompok peminjam sebagai pemanfaat dana bergulir, dengan cara pengajuan proposal pinjaman kepada Penganggungjawab Operasional Kegiatan (PJOK). Proposal tersebut memaparkan tentang data anggota kelompok. Besarnya jumlah pinjaman paling sedikit $R p$ 1.500.000,00 sampai dengan $\mathrm{Rp} 2.000 .000,00$ dengan tingkat suku bunga sebesar $1,5 \%$ perbulan dengan sistem falte rate, yang akan diangsur selama 12 kali.

Dalam memberikan bantuan melaui PNPM Mandiri biasanya tidak adanya jaminanyang harus diberikan oleh si peminjam karena bantuan ini merupakan program

Jurnal Ilmiah Al Tsarwah

Program Magister Program Studi Ekonomi Syariah

Institut Agama Islam Negeri (IAIN) Bone 
yangbersifat nasional sedangkan apabila terjadi keterlambatan pembayaran maka sanksiyang diberikan adalah tidak akan diberikan pinjaman untuk masa yang akan dating oleh pihak yang menyalurkan pinjaman.Maka dengan demikian dapat juga dilihat bahwa sebelum adanya PNPM Mandiri inimaka para pengusaha kecil sering terlihat kekurangan dana serta banyak yang matiusahanya namun setelah adanya bantuan PNPM usaha UKM kembali bergairahkarena adanya suntikan dana segar dari pihak Pemerintah yang tidak menggunakanagunan.

Berdasarkan latar belakang yang telah diuraikan diatas maka penulis tertarik untuk melakukan penelitian dengan judul "Dampak Pelaksanaan Program nasional Pemberdayaan Masyarakat (PNPM) Mandiri Terhadap Peningkatan Pendapatan Masyarakat Miskin di Desa Tompobulu Kecamatan Rumbia Kabupaten Jeneponto".

Berdasar pada uraian-uraian yang telah dipaparkan, maka permasalahan pokok yang dijadikan obyek bahasan Bagaimana pengaruh pinjaman dana bergulir oleh PNPM Mandiri terhadap pendapatan Masyarakat Miskin di Desa Tompobulu Kecamatan Rumbia Kabupaten Jeneponto .

\section{METODE}

\section{Variabel penelitian}

Berdasarkan karakteristik masalah yang diteliti, maka penelitian ini dapat diklasifikasikan ke dalam penelitian deskriptif kuantitatif yang bertujuan untuk menguji hipotesis atau menjawab masalah yang berupa fakta saat ini dari suatu populasi.Penelitian deskriptif adalah salah satu jenis penelitian yang tujuannya untuk menyajikan gambaran lengkap mengenai hubungan antara fenomena yang di uji.

Variabel dalam penelitian ini adalah pinjaman dana bergulir oleh PNPM Mandiri sebagai variabel $X$ dan Peningkatan pendapatan Masyarakat Miskin sebagai variabel $Y$

\section{Defenisi operasional variabel}


Definisi operasional menjelaskan cara tertentu yang digunakan oleh peneliti dalam mengukur suatu variabel yang akan digunakan. Definisi operasional variabelvariabel dalam penelitian ini adalah sebagai berikut:

1. PNPM yaitu program nasional penanggulangan kemiskinan terutama yang berbasis pemberdayaan masyarakat.

2. Pinjaman dana bergulir, yaitu pinjaman modal yang digunakan untuk mengembangkan kegiatan usaha ekonomi produktif

3. Pendapatan usaha, yaitu jumlah rupiah yang diterima dari hasil penjualan barang dagangan selama satu bulan dikurangi total biaya usaha selama satu bulan.

\section{Populasi dan sampel}

\section{Populasi}

Sulistyo-Basuki $(2006 ; 182)$ mengemukakan populasi adalah keseluruhan objek yang akan diteliti. Sedangkan menurut Suhrsimi Arikunto mengemukakan bahwa populasi adalah totalitas semua nilai yang mungkin, hasil menghitung atau pengukuran, kuantitatif maupun kualitatif mengenai karakteristik tertentu dari semua anggota kumpulan yang lengkap dan jelas yang ingin dipelajari sifatsifatnya.

Populasi dalam penelitian ini adalah rumah tangga miskin di Desa Tompobulu Kecamatan Rumbia Kabupaten Jeneponto yang mendapat bantuan dari program PNPM mandiri yang berjumlah 6 kelompok dengan jumlah rumah tangga miskin sebanyak 30 .

\section{Sampel}

Sampel adalah bagian dari populasi yang diharapkan mampu mewakili populasi dalam penelitian. Untuk menentukan besarnya sampel menurut Arikunto $(2002 ; 112)$ apabila subjek kurang dari 100, lebih baik diambil semua sehingga penelitiannya penelitian populasi. Jika subjeknya lebih besar dapat diambil antara $10-15 \%$ atau $20-25 \%$. Dalam penelitian ini populasinya adalah 36 Rumah tangga miskin sehingga penelitian ini termasuk penelitian populasi 
sehingga populasi dalam penelitian ini sekaligus menjadi sampel yaitu sebesar 30 rumah tangga miskin.

\section{Jenis dan sumber data}

Jenis dan sumber data penelitian merupakan faktor yang penting dan menjadi pertimbangan untuk menentukan metode pengumpulan data. Adapun Jenis data yang di gunakan dalam penelitian ini adalah data primer yaitu data yang di peroleh peneliti secara langsung dari sumber asli

\section{Teknik pengumpulan data}

Data yang digunakan dalam penelitian ini di peroleh dalam bentuk Penelitian Kepustakaan (Library Research) dan penelitian langsung di lapangan. Penelitian Kepustakaan (Library Research) yaitu teknik pengumpulan data dengan membaca dan menelusuri sejumlah literatur yang berhubungan dengan pembahasan dalam penelitian ini.

\section{Metode analisis data}

Untuk mengetahui pengaruh pinjaman dana bergulir oleh PNPM Mandiri terhadap pendapatan masyarakat miskin di Desa Tompobulu Kecamatan Rumbia Kabupaten Jeneponto, dilakukan uji regresi sederhana dengan menggunakan rumus:

$$
\begin{aligned}
& \mathrm{Y}=\alpha+\beta_{1} \mathrm{X}+\mathrm{e} \\
& \text { Dimana : } \\
& \mathrm{Y} \quad=\text { Pendapatan Masyarakat Miskin } \\
& \mathrm{X}=\text { Pinjaman Dana Bergulir Oleh PNPM Mandiri } \\
& \alpha \quad=\text { Konstanta } \\
& \beta_{1} \quad=\text { Koefisien regresi } \\
& \mathrm{e}=\text { Error term }
\end{aligned}
$$

\section{a. Uji Koefisien regresi}

Untuk mendapatkan nilai $\alpha$ dan $\beta$ digunakan rumus : 


$$
a=\frac{\left(\sum \mathrm{y}\right)\left(\sum_{\mathrm{x}} 2\right)-\left(\sum \mathrm{x}\right)\left(\sum \mathrm{xy}\right)}{\mathrm{n}\left(\sum_{\mathrm{x}} 2\right)-\left(\sum \mathrm{x}\right) 2}
$$

$$
\beta=\frac{\mathrm{n}\left(\sum \mathrm{xy}\right)-\left(\sum \mathrm{x}\right)\left(\sum \mathrm{y}\right)}{\mathrm{n}\left(\sum_{\mathrm{x}} 2\right)-\left(\sum \mathrm{x}\right) 2}
$$

Dalam penelitian ini untuk mendapatkan nilai $\alpha$ dan $\beta$ mengunakan bantuan SPSS 20

\section{b. Uji Determinasi $\left(\mathbf{R}^{2}\right)$}

Uji Determinasi $\left(R^{2}\right)$ digunakan untuk menunjukkan besarnya variabel independen dalam mempengaruhi variabel dependen. Nilai $\mathrm{R}^{2}$ berkisar antara 0 dan $1\left(0 \leq R^{2} \leq 1\right)$. Semakin besar nilai $R^{2}$, maka semakin besar variasi variabel dependen yang dapat dijelaskan oleh variasi variabel independen. Sifat dari koefisien determinasi sebagai berikut :

a. $R^{2}$ merupakan besaran yang non negatif

b. Batasannya adalah $\left(0 \leq R^{2} \leq 1\right)$.

Apabila R2 bernilai 0 berarti tidak ada hubungan antara variabel independen dengan variabel dependen.Semakin besar nilai R2 maka semakin tepat garis regresi dalam menggambarkan nilai-nilai observasi.

\section{HASIL DAN PEMBAHASAN}

Pengaruh Pinjaman Dana Bergulir terhadap Pendapatan masyarakat miskin di Desa Tompobulu Kecamatan Rumbia Kabupaten Jeneponto 
Berdasarkan hasil olah data dengan menggunakan spss 20 hasilnya adalah sebagai berikut :

\section{Tabel \\ Nilai Koefisien Regresi Sederhana}

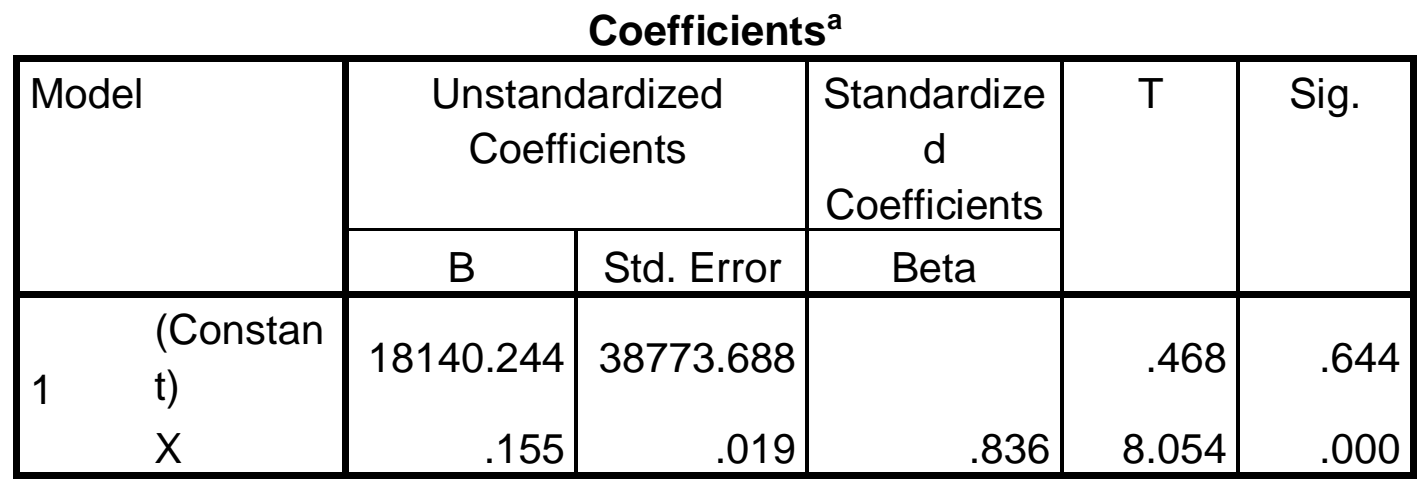

a. Dependent Variable: $Y$

Dari hasil pengolahan data melalui SPSS 20 diperoleh persamaan regresi sebagai berikut :

$$
Y=18140.24+0,155 X
$$

Hal tersebut menunjukkan bahwa nilai konstanta sebesar 18140.24menyatakan bahwa jika tidak ada pinjaman dana bergulir dari PNPM Mandiri, maka pendapatan yang dimiliki adalah sebesar Rp 18.140.24. Sedangkan nilai koefisien regresi sebesar 0,155 menyatakan bahwa setiap pinjaman $\mathrm{Rp} 1$ dana bergulir maka akan menyebabkan peningkatan pendapatan sebesar $\mathrm{Rp} 0,155$, atau jika menerima pinjaman dana bergulir dari PNPM Mandirisebesar Rp 1.000.000,- maka besarnya pendapatan masyarakat adalah Rp 155.000,- Jadi arah tanda positif (+) menyatakan bahwa arah hubungan antara Pinjaman dana bergulir dengan pendapatan Masyarakat adalah searah. Dimana kenaikan atau penurunan pinjaman dana bergulir dari PNPM Mandiri akan mengakibatkan kenaikan atau penurunan pada pendapatan Masyarakat. 
1. Analisis Korelasi antara Pinjaman dana bergulir dari PNPM Mandiri dengan PendapataMasyarakat di Desa Tompobulu Kecamatan Rumbia Kabupaten Jeneponto

Berdasarkan hasil olah data dengan menggunakan spss 20 hasilnya adalah sebagai berikut :

Tabel 4.8

Nilai Koefisien Korelasi

Correlations

\begin{tabular}{|rl|r|r|}
\hline & & \multicolumn{1}{|c|}{ X } & \multicolumn{1}{|c|}{ Y } \\
\hline \multirow{4}{*}{ X } & Pearson Correlation & 1 & $.836^{* *}$ \\
& Sig. (2-tailed) & & .000 \\
& N & 30 & 30 \\
& Pearson Correlation & $.836^{* *}$ & 1 \\
Y & Sig. (2-tailed) & .000 & \\
& N & 30 & 30 \\
\hline
\end{tabular}

${ }^{* *}$. Correlation is significant at the 0.01 level $(2-$ tailed).

Dari hasil pengolahan data melalui SPSS 20 pada tabel diatas diperoleh nilai koefisien korelasi sebesar 0,836 yang artinya bahwa besar hubungan antar variabel pedapatan usaha lammang dengan pendapatan rumah tangga menunjukkan hubungan positif yang sangat erat.

2. Analisis Koefisien Determinasi antara Pinjaman dana bergulir dari PNPM Mandiri dengan PendapataMasyarakat di Desa Tompobulu Kecamatan Rumbia Kabupaten Jeneponto

Berdasarkan hasil olah data dengan menggunakan spss 20 hasilnya adalah sebagai berikut :

Jurnal Ilmiah Al Tsarwah

Program Magister Program Studi Ekonomi Syariah

Institut Agama Islam Negeri (IAIN) Bone 


\section{Nilai Koefisien Determinasi}

\section{Model Summary}

\begin{tabular}{|l|r|r|r|c|}
\hline Model & $\mathrm{R}$ & $\mathrm{R}$ Square & $\begin{array}{c}\text { Adjusted R } \\
\text { Square }\end{array}$ & $\begin{array}{c}\text { Std. Error of } \\
\text { the Estimate }\end{array}$ \\
\hline 1 & $.875^{\mathrm{a}}$ & .765 & .757 & 44035.96190 \\
\hline
\end{tabular}

a. Predictors: (Constant), $\mathrm{X}$

Dari hasil pengolahan data melalui SPSS 20 pada tabel 4.9 diatas diperoleh nilai R Square sebesar 0,765 yang artinya bahwa $76,50 \%$ variasi perubahan pendapatan Masyarakat dapat dijelaskan oleh variabel pinjaman dana bergulir oleh PNPM Mandiri di Desa Tompobulu Kecamatan Rumbia Kabupaten Jeneponto. Sedangkan selebihnya sebesar $23,50 \%$ dipengaruhi oleh variabel lain.

\section{Uji Hipotesis (uji t)}

Untuk menguji hipotesis bahwa variabelpinjaman dana bergulir mempunyai pengaruh yang signifikan terhadap pendapatan Masyarakatdi Desa Tompobulu Kecamatan Rumbia Kabupaten Jeneponto Kabupaten Jeneponto maka dilakukan Uji t.Adapun hipotesis yang diajukan adalah :

$\mathrm{H}_{0}: \beta_{\mathrm{i}}=0$ : Tidak terdapat pengaruh signifikan variabel Pinjaman dana bergulir oleh PNPM Mandiri terhadap pendapatan masyarakat di Desa Tompobulu Kecamatan Rumbia Kabupaten Jeneponto

$\mathrm{H}_{a}: \beta_{\mathrm{i}} \neq 0$ : terdapat pengaruh signifikan variabel Pinjaman dana bergulir oleh PNPM Mandiri terhadap pendapatan masyarakat di Desa Tompobulu Kecamatan Rumbia Kabupaten Jeneponto 
Proses pengujian dilakukan dengan melihat pada kolom signifikansi dan nilai t di tabel 4.6dengan mengunakan tingkat signifikansi $(\alpha)$ sebesar $5 \%$ atau 0.05 Adapun dasar pengambilan keputusannya yaitu :

Jika signifikansi $<0,05$, maka $\mathrm{H}_{0}$ ditolak (rejected)

Jika signifikansi $>0,05$, maka $\mathrm{H}_{0}$ diterima ( notrejected)

Berdasarkan hasilolah data dengan menggunakan SPSS 20 diperoleh Nilai signifikansi sebesar 0.000 lebih kecil dari taraf signifikansi yang ditetapkan dalampenelitian ini yaitu 0,05 $(0,000<0,05)$, dapat diinterpretasikan bahwa hipotesis yang diajukan dalam penelitian ini diterima, dengan kata lain terdapat pengaruh positif signifikan variabel Pinjaman dana bergulir oleh PNPM Mandiri terhadap pendapatan masyarakat di Desa Tompobulu Kecamatan Rumbia Kabupaten Jeneponto.

\section{KESIMPULAN DAN SARAN}

\section{Kesimpulan}

Program PNPM Mandiri yaitu pinjaman dana bergulir berpengaruh positif signifikan terhadap peningkatan pendapatan masyarakat miskin di Desa Tompobulu Kecamatan Rumbia Kabupaten Jeneponto, dengan demikain Pemberian pinjaman dana bergulir kepada masyarakat miskin oleh PNPM Mandiri dapat menigkatkan pendapatan masyarakat miskin di Desa Tompobulu Kecamatan Rumbia Kabupaten Jeneponto.

\section{Saran}

Berdasarkan hasil penelitian ini maka penulis menyarankan pada pemerintah untuk meningkatkan bantuan pinjaman dana bergulir oleh PNPM Mandiri kepada masyarakat miskin karena berpengaruh langsung terhadap peningkatan pendapatan masyarakat miskindi Desa Tompobulu Kecamatan Rumbia Kabupaten Jeneponto.

\section{DAFTAR PUSTAKA}

Mulyadi, 2007.Pengantar Manajemen, Anibraw, Jakarta. 
N, Dunn, William, 2005. Analisis Kebijakan Publik, Gadjah Mada University Press,Yogyakarta.

Nucholis, Hanif, 2005. Pemerintahan dan Otonomi Daerah, Garsindo, Jakarta.

Soejono dan Abdurahman, 2002. Metode Penelitian, Rineka Cipta, Jakarta.

Mastura Labombang, 2007, Dampak Pembangunan InfrastrukturPedesaan pada Program PNPM Mandiri Pedesaan di Kabupaten Toli-Toli. Jurusan Teknik Sipil Fakultas Teknik Universitas Tadulako, Palu

Rahmatika (2010)Analisis efektifitas Program pinjaman dana bergilir pada unit pengelola kegiatan (UPK) PNPM Mandiri dan kelompok simpan pinjam perempuan (SPP) di Kecamatan Situjuh Limo Nagari Kabupaten Lima puluh kota tahun 2008-2010.Skripsi Program studi manajemen fakultas ekonomi universitas andalas Padang

Dian Novitasari (2011) Analisis program PNPM mandiri terhadap peningkatan pendapatan masyarakat miskin di Kecamatan Andong Kabupaten Boyolali tahun 2009. Fakultas Ekonomi Universitas sebelas maret Surakarta

Muhammad Sukri (2013)studi kualitatif dampak PNPM-p

Wahyu Hamidi, Jahrizal, dan Susi Susanti (2010) Dampak Program nasional Pemberdayaan Masyarakat Mandiri (PNPM) terhadap pendapatan masyarakat di Kecamatan Kuantan Hilir Kabupaten Kuantan Singingi.Jurusan Ilmu Ekonomi Fakultas Ekonomi Universitas Riau Kampus Bina Widya Km 12,5 Simpang Baru - Pekanbaru 28293. 
Jurnal Ilmiah Al Tsarwah

Program Magister Program Studi Ekonomi Syariah Institut Agama Islam Negeri (IAIN) Bone 